\title{
KETAHANAN KELUARGA SEBAGAI BASIS PENDIDIKAN DI TENGAH PANDEMI COVID 19
}

\author{
Dwi Yunianto ${ }^{1)} *$ \\ ${ }^{1}$ Program Magister Ilmu Agama Islam, \\ Universitas Islam Indonesia (UII), Yogyakarta \\ *E-mail: dwilezat@yahoo.co.id
}

\begin{abstract}
This paper aims to describe the role of parents as educators to their children in the midst of the corona virus outbreak in the family environment. This paper uses a qualitative method with a descriptive analysis approach. The background of this paper is because many parents do not know their obligation to provide education to their children, especially in the family. Education in schools has apparently not been able to fully educate students, especially in the fields of religion and morals, this is evident by many students who do not understand religion, reading the Qur'an, are also increasingly widespread juvenile delinquency, ranging from fights, drugs and so forth. The purpose of education in the family is so that children are able to develop optimally both physically, spiritually and intellectually. The role of parents in the education process is to use all means or methods such as example, advice, story or punishment. The role that is no less important is that parents provide educational material such as religious, social, physical, moral and intellectual education.
\end{abstract}

Keywords: Family, Base, Education

\begin{abstract}
Abstrak
Makalah ini bertujuan untuk mendeskripsikan peranan orang tua sebagai pendidik kepada anak-anaknya di tengah wabah virus corona di lingkungan keluarga. Makalah ini menggunakan metode kualitatif dengan pendekatan analisis deskriptif. Adapaun latar belakang makalah ini adalah karena banyak orang tua belum tahu kewajibanya yaitu memberikan pendidikan kepada anak anaknya terutama di keluarga. Pendidikan di sekolahan ternyata belum mampu sepenuhnya mendidik para peserta didik khususnya dalam bidang agama maupun moral, ini terbukti banyak peserta didik yang belum paham agama, membaca Al quran, juga makin marak kenakalan remaja, mulai dari perkelahian, narkoba dan lain sebagainya. Tujuan pendidikan dalam keluarga yaitu agar anak mampu berkembang maksimal baik jasmani, rohani dan akalnya. Peran orang tua dalam proses pendidikan adalah menggunakan semua sarana atau metode seperti keteladan, nasehat, kisah atau hukuman. Peran yang tidak kalah penting adalah orang tua memberikan materi pendidikan seperti pendidikan agama, sosial, jasmani, moral dan akal.
\end{abstract}

Kata Kunci: Keluarga, Basis, Pendidikan

\section{PENDAHULUAN}

Adanya wabah covid 19, di mana anak-anak pesantren dikembalikan ke rumah, proses pendidikan sekolahan dari rumah, dan diajurkan banyak tinggal di rumah, seolah orang tua diingatkan tentang pendidikan dalam kelurga yang barangkali dilupakan oleh sebagian orang tua. Orang tua hendaknya mengingat salah satu kunci 


\section{2 | Dwi Yunianto}

sukses adalah mementingkan pendidikan keluarga, karena sukses di dunia bisa menuju sukses akhirat.

Pendidikan di sekolah ternyata belum mampu menjawab kegelisahan orang tua dan masyarakat, ini terbukti masih banyak yang belum memahami agama dengan baik, baik dalam aqidah, ibadah maupun membaca Al Quran. Demikian juga banyak kasus kenakalan remaja dan siswa sekolah yang semakin merebak. Kenakalan remaja mulai dari tawuran antar siswa , narkoba, seks bebas, minuman keras, sampai kepada krisis moral, sebagai contoh adanya siswa yang mengancam atau bahkan membunuh gurunya sendiri lantaran tidak terima di ingatkan tatkala merokok.

Pendidikan keluarga akan memperbaiki anak mulai dari agama , akhlak, sosial dan lain sebagainya. Keberhasilan Pendidikan keluarga akan menjadi perantara bagi orang tua menuju surga dunia (rumahku surgaku) dan juga menuju surga akhirat. Adanya Anak-anak yang sholih dan sholihah, akan menjadikan kebaikan yang anak lakukan menjadi pahala yang mengalir bagi orang tua.

Demikian juga dalam keluarga akan menjadi pintu yang besar bagi anak untuk masuk kedalam surga akhirat, manakala dia termasuk anak yang selalu mendoakan orang tua, berbakti, dan tidak menyakitinya baik dengan perkataan maupun perbuatan.

Tentang urgensinya peran keluarga dalam mendidik anak, Ibnul Qoyyim mengatakan, bahwa kerusakan anak sebagian dipicu oleh orang tua, yakni ketidak pedulian mereka, mereka tidak mengajarkan kewajiban-kewajiban dan sunah-sunah agama kepada anak-anak, mereka menelantarkan anak-anak sejak masih kecil sehingga anak-anak tidak memetik manfaat dari mereka sendiri, juga tidak memberi manfaat bagi orang tua kala menginjak usia senja (Hasan Syamsi, 2004, 10 ).

Imam Al-Ghazali menuturkan, bahwa ketika anak diabaikan pada masa pertumbuhan awal, umumnya ia akan menjadi orang berakhlak buruk seperti pendusta, pendengki, pencuri, suka mengadu domba, suka meminta, suka melakukan hal-hal tiada guna, suka tertawa, dan bertindak gila, semua ini bisa dihindari dengan pendidikan yang baik (Hasan Syamsi, 2004, 14).

\section{METODE}

Artikel ini menggunakan metode kualitatif dengan pendekatan analisis deskriptif, jenis penelitian deskriptif kualitatif merupakan sebuah metode penelitian 
yang memanfaatkan data kualitatif dan dijabarkan secara deskriptif, penelitian ini digunakan untuk menganalisa kejadian, fenomena, atau keadaan secara sosial. Menurut Jane Richie, penelitian kualitatif adalah upaya untuk menyajikan dunia sosial, dan perspektifnya di dalam dunia, dari segi konsep, perilaku, persepsi,dan persoalan tentang manusia yang diteliti ( L.J. Moleong, 2016, 6).

\section{PEMBAHASAN}

\section{Pendidikan dalam Rumah Tangga}

\section{Pendidik (Orang Tua)}

Orang tua adalah pendidik dalam rumah tangga bagi anak-anaknya, karena dari merekalah anak pertama kali mendapatkan pendidikan. Orang tua harus sadar bahwa anak adalah amanah yang akan dimintai pertanggung jawaban di akhirat, sehingga anak tidak cukup diberi materi yang sifatnya lahiriyah, tapi anak juga wajib diberikan materi rohaniyah, sabda Rasulullahi shollallahu 'alaihi wasallam:

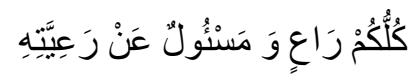

"Setiap kalian adalah pemimpin, dan setiap pemimpin akan dimintai pertanggung jawaban atas yang dipimpinnya " (HR.Bukhori: 2232)

\section{Peserta didik (Anak)}

Peserta didik di sini adalah anak itu sendiri walaupun sebenarnya semua bisa masuk dalam peserta didik, tetapi dalam hal pendidikan dalam rumah tangga anak menjadi obyek terdidik. Allah berfirman dalam QS At Tahrim ayat 6:

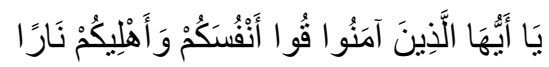

"Hai orang-orang yang beriman, peliharalah dirimu dan keluargamu"

\section{Sarana - sarana Pendidikan}

a. Keteladanan

Syekh Abdullah Nashih Ulwan dalam kitabnya Tarbiyatul Aulād Fil Islām menerangkan bahawa cara ini adalah cara yang sangat efektif dan berpengaruh untuk membentuk akhlak anak, hal ini disebabkan karena pendidik adalah contoh figur dalam pandangan anak. Anak perlahan akan mengikuti kebiasaan perilaku sang pendidik baik sadar atau tidak sadar, bahkan akan mengikuti kejiwaan, perasaan, ucapan, perbuatan yang nampak 
atau yang tidak, baik dia tahu atau tidak tahu (Abdullah Nashih Ulwan, 1981, 607). Allah berfirman dalam QS Al Ahzab ayat 21:

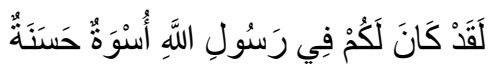

"Sesungguhnya telah ada pada (diri) Rasulullah itu suri teladan yang baik bagimu "

Tatkala ditanyakan kepada Aisyah radhiyallahu 'anha tentang akhlak Rasulullahi shollallahu 'alaihi wasallam, maka Aisyah menjawab, akhlak beliau adalah Al Quran. Rasulullahi shollallahu 'alaihi wasallam adalah contoh dalam semua hal bagi kaum muslimin. Maka, sebagai pendidik hendaknya orang tua memberi keteladanan bagi anaknya, sehingga anak akan mencontoh kebiasaan baik orang tuanya.

b. Kisah

Kisah mempunyai pengaruh besar dalam pendidikan, dikarenakan tabiat manusia mempunyai rasa ingin tahu terhadap sesuatu yang belum diketahui (majhul), dalam kisah juga mencakup hal-hal yang membuat rindu, itulah sebabnya dalam Al Quran banyak bercerita tentang kisah-kisah, Allah berfirman dalam QS Yusuf ayat 111:

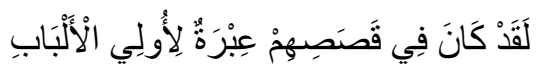

"Sesungguhnya pada kisah-kisah mereka itu terdapat pengajaran bagi orangorang yang mempunyai akal"

Orang tua hendaknya memilih cerita yang bermanfaat dan mendidik baik dalam aqidah, akhlaq, ilmu, dan sastra. Kisah-kisah bisa diambilkan dari $\mathrm{Al}$ Quran, kisah para nabi, kisah para shahabat, kisah para ulama atau kisah tentang perjuangan kaum muslimin.

c. Nasehat dan Peringatan

Nasehat dibutuhkan karena kecenderungan manusia yang sering lalai, dengan nasehat akan membuka jiwa, dan hati akan mengingat. Betapa banyak manusia dengan sabab nasehat kemudian menjadi baik, kembali ke jalan yang benar, menyesali dosa-dosa, meneteskan air mata taubat kepada Allah.

Orang tua hendaknya tidak bosan-bosan memberi nasehat kapada anakanaknya, Allah menceritakan Luqman tatkala memberi nasehat kepada putranya dalam QS Luqman ayat 13: 


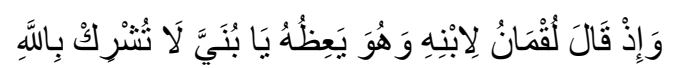

"Dan (ingatlah) ketika Luqman berkata kepada anaknya, di waktu ia memberi pelajaran kepadanya: "Hai anakku, janganlah kamu mempersekutukan Allah, sesungguhnya mempersekutukan (Allah) adalah benar-benar kezaliman yang besar"

d. Kejadian dan Peristiwa

Bagian dari pendidikan adalah dengan mengambil pelajaran dari suatu kejadian dan peristiwa, misalnya tatkala terjadi gempa, orang meninggal dunia, orang terkena penyakit, maka seseorang akan mudah mengambil pelajaran semisal mengingat kematian, mengingat kebesaran Allah, menjauhi sifat sombong dan lain sebagainya. Allah berfirman dalam QS At Taubah ayat 25:

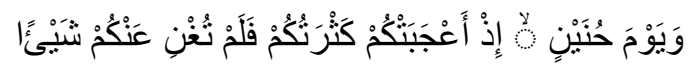

"dan (ingatlah) peperangan Hunain, yaitu diwaktu kamu menjadi congkak karena banyaknya jumlah (mu)"

Orang tua bisa memanfaatkan pendidikan dari suatu peristiwa semisal tatkala hujan, agar anak mengingat kebesaran Allah dan mensyukuri nikmat Allah.

e. Hukuman

Perlu diketahui bahwa asal pendidikan adalah dengan kelembutan, karena jiwa akan lebih mudah menerima suatu nasehat bila disertai dengan kelembutan dan sentuhan hati. Tapi karena manusia itu bermacam - macam tingkatannya, ada yang asalnya memang anak itu baik, sehingga mudah diatur, tapi adakalanya anak itu kurang baik, apakah karena faktor teman, lingkungan, atau yang lainya, sehingga perlu diterapkan suatu hukuman, agar anak kembali menjadi baik.

Penerapan hukuman tentunya dilakukan setelah proses nasehat dan peringatan yang paling ringan, mulai teguran dengan perkataan lembut, meningkat ke perkataan keras, sampai pada hukuman. Allah berfirman dalam QS An Nisa ayat 34:

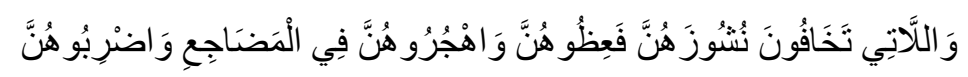

"Wanita-wanita yang kamu khawatirkan nusyuznya, maka nasehatilah mereka dan pisahkanlah mereka di tempat tidur mereka, dan pukullah mereka“ 
Rasulullahi shollallahu 'alaihi wasallam bersabda: "Perintahkanlah anakanak kalian untuk melaksanakan shalat apabila sudah mencapai umur tujuh tahun, dan apabila sudah mencapai umur sepuluh tahun maka pukullah dia apabila tidak melaksanakannya, dan pisahkanlah mereka dalam tempat tidurnya." (HR Abu Daud : 418)

f. Tanya jawab

Tanya jawab adalah salah satu metode pengajaran yang sangat efektif, dengan bertanya maka orang yang ditanya akan mengerahkan kemampuan untuk bisa menjawab, tatkala dia tidak bisa menjawab maka dia akan siap untuk menerima ilmu yang dia tidak ketahui.

Rasulullahi Shollallahu 'alaihi wasallam sering bertanya kepada shahabat semisal Muadz bin jabal dengan tujuan memberikan ilmu kepada Muadz. Demikian juga dalam Al Quran banyak kita temukan tentang metode tanya jawab. Allah berfirman dalam QS al Qori'ah ayat 2-3:

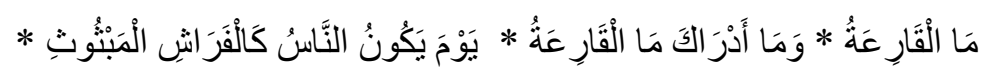

"Apakah hari Kiamat itu? Tahukah kamu apakah hari Kiamat itu? Pada hari itu manusia adalah seperti anai-anai yang bertebaran"

\section{Kunci Keberhasilan Pendidikan dalam Rumah Tangga}

a. Keikhlasan

Agar pendidikan sukses maka di perlukan keikhlasan baik bagi pendidik (orang tua) maupun yang terdidik (anak), ikhlas akan mendatangkan kerelaan, tanpa pamrih dan penuh cinta, sedangkan tanpa keikhlasan akan mendatangkan keterpaksaan, marah dan kedengkian. Seorang muslim hendaknya membangun aktifitas kebaikannya dengan mencari ridho Allah, berharap pahala di akhirat.

b. Kesabaran

Mendidik manusia apalagi anak-anak perlu adanya kesabaran, mendidik bukan seperti membuat makanan yang bisa kemudian langsung jadi, tapi pendidikan mungkin perlu waktu panjang dan bertahun-tahun. Rasulullahi shollallahu 'alaihi wasallam dalam mendidik para shahabat membutuhkan waktu lama, 13 tahun di Mekah dan 10 tahun di Madinah. Allah berfirman dalam QS Al 'Ashr ayat 3:

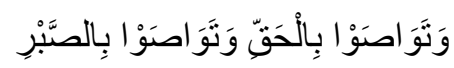


"..dan nasehat menasehati supaya mentaati kebenaran dan nasehat menasehati supaya menetapi kesabaran"

c. Doa

Doa adalah wujud ikhtiar seorang manusia sehingga orang tua sangat butuh dengan doa, karena dengan doa Allah akan memudahkan mendidik anak-anaknya, anak akan mudah menerima pendidikan. Allah berfirman dalam QS As Shoffat ayat 100:

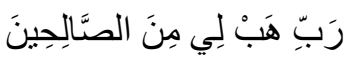

(Ibrahim) berdoa, "Ya Tuhanku, anugrahkanlah kepadaku (seorang anak) yang termasuk orang-orang yang shaleh “

Seorang kekasih Allah yaitu Ibrahim memohon kepada Allah agar diberikan anak yang shalih, bagaimana dengan kita yang bukan utusan Allah, tentu kita sangat butuh pertolongan Allah.

d. Komitmen

Saling komitmen antara pendidik dan yang terdidik adalah salah satu kunci keberhasilan dalam pendidikan. Komitmen dengan materi pengajaran, komitmen dengan jadwal, komitmen dengan pelaksanaan hasil dari pendidikan tersebut.

\section{Prinsip - prinsip Pendidikan Anak dalam Rumah Tangga}

a. Pendidikan Agama

1) Tauhid

Membangun Aqidah yang benar pada diri anak sejak dini sangatlah penting, tentu dengan mempertimbangan usia dan kematangan berfikir, jangan membebani anak diluar kemampuan. Mengenalkan Allah kepada anak dengan pertanyaan-pertanyaan ringan, misal "siapa yang menciptakan manusia?, siapa yang menurunkan hujan?”. Demikian juga membiasakan berdoa tatkala mau makan, mau tidur dengan membaca basmallah, mensyukuri nikmat Allah dengan membaca hamdallah, mengenalkan anak tentang balasan orang baik adalah surga dan balasan orang buruk adalah neraka, dan lain sebagainya.

2) Sholat

Anak usia empat atau lima tahun bisa dilatih wudhu dan sholat, dan diajak untuk mengerjakan sholat. Biasakanlah mengajak anak ke masjid 
untuk sholat dengan tetap mengawasinya, memberi nasehat agar tidak ramai dan ajarkan etika-etika di dalam masjid. Tanamkan dengan lemah lembut bahwa Allah mencintai anak-anak yang sholat. Allah berfirman dalam QS Thaha ayat 132:

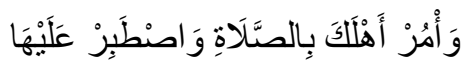

"Dan perintahkanlah kepada keluargamu mendirikan shalat dan bersabarlah kamu dalam mengerjakannya"

3) Al Quran

Dalam Muqoddimahnya Ibnu Khaldun menegaskan konsep mengajarkan Al Quran kepada anak-anak, ia mengatakan bahwa mengajarkan Al Quran kepada anak-anak merupakan salah satu bentuk syiar agama yang di praktekkan para pemeluk islam di seluruh wilayah, karena cara ini memperkuat iman dan aqidah di hati anak melalui ayat $\mathrm{Al}$ Quran dan matan - matan hadist, Al Quran menjadi asas pendididkan yang menopang segala kemampuan anak di kemudian hari (Hasan Syamsi, 2004, 64).

Hadits berikut menunjukkan betapa mulia orang yang mengajarkan al-Qur'an,

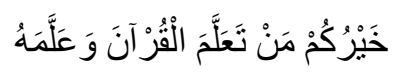

"Sebaik-baik kalian adalah yang belajar Al Quran dan mengajarkannya." (HR Bukhari dari Utsman bin 'Affan Radhiyallahu'anhu ).

b. Pendidikan Akhlaq

Pendidikan yang sangat urgent kepada anak adalah pendidikan akhlaq, ajarkan anak tentang akhlak kepada Allah, kepada Nabi, orang tua dan sesama manusia. Tanamkan nilai-nilai kebaikan seperti amanah, jujur, tangung jawab, mandiri, disiplin, kasih sayang, itsar ( mendahulukan orang lain ), adil dan lain sebagainya. Allah berfirman:

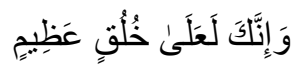

"Dan sesungguhnya kamu (muhammad) benar-benar berbudi pekerti yang agung“. (Surat Al Qolam: 4)

Termasuk pada pendidikan bab ini adalah mengajarkan anak adab, seperti adab bermajlis, makan, di kamar mandi, memakai pakaian, berbicara, tidur dan lain sebagainya. 
c. Pendidikan Jasmani

Pendidikan jasmani terutama pada anak sangat penting, sehingga ada istilah, " di dalam tubuh yang sehat terdapat jiwa yang kuat". Maksud dari pendidikan jasmani adalah pendidikan yang ada hubungan erat dengan pertumbuhan dan kesehatan jasmani anak, semisal anak diajarkan olah raga. Rasulullah shallallahu alaihi wa sallam bersabda,

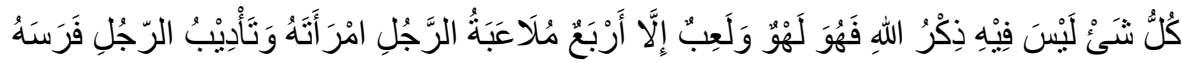

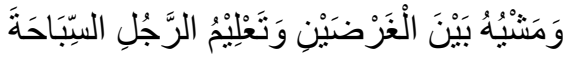

"Segala sesuatu yang tidak mengandung dzikirullah padanya maka itu adalah kesia-siaan dan main-main kecuali empat perkara: yaitu senda gurau suami dengan istrinya, melatih kuda, berlatih memanah, dan mengajarkan renang." (H.R, An Nasai : 8940 )

d. Pendidikan Akal

Salah satu mensyukuri nikmat Allah adalah memaksimalkan nikmat Allah berupa akal.

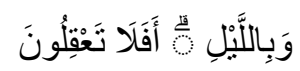
"dan di waktu malam. Maka apakah kamu tidak memikirkan?" (QS Ash Shaffat: 138)

Yang di maksud pendidikan akal adalah membentuk pemikiran anak dengan sesuatu yang bermanfaat seperti ilmu pasti, ilmu alam, teknologi modern dan peradaban. Pendidikan agama merupakan pembentukan dasar, pendidikan jasmani sebagai persiapan, pendidikan moral untuk membentuk akal, sedangkan pendidikan akal untuk penyadaran.

e. Pendidikan Sosial

Pendidikan sosial adalah pendidikan anak agar anak terbiasa melakukan tatakrama sosial yang bersumber dari akidah islamiyah dan kebiasaan masyarakat yang baik. Pendidikan sosial merupakan salah satu aspek pendidikan anak dan merupakan aplikasi dari aspek-aspek pendidikan, karena pendidikan sosial merupakan fenomena tingkah laku yang dapat mendidik anak guna melakukan segala kewajiban sopan santun dalam berinteraksi dengan orang lain secara baik. Rasulullah shallallahu alaihi wa sallam bersabda:

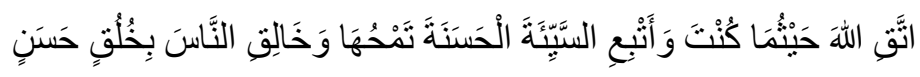


"Bertakwalah kepada Allah di mana saja engkau berada. Iringilah kejelekan dengan kebaikan, niscaya kebaikan itu akan menghapuskan kejelekan tersebut, dan bergaullah dengan manusia dengan akhlak yang baik." (HR. Tirmidzi, 1910)

\section{Tujuan Pendidikan dalam keluarga}

Tujuan adanya pendidikan dalam keluarga adalah terbentuknya insan -insan yang beriman dan bertaqwa kepada Allah Subhanahu wa Ta'ala, serta berakhlak mulia yang mencakup etika, moral, budi pekerti, serta mengamalkan nilai-nilai agama dalam kehidupan sehari hari baik di lingkungan keluarga dan masyarakat.

Tujuan pendidikan dalam keluarga ialah agar anak mampu berkembang maksimal baik jasmani, rohani maupun akalnya. Menjadi Anak - anak yang shalih dan shalihah. Termasuk tujuan pendidikan keluarga adalah menjadi keluarga yang sakinah waddah wa rahmah, rumah yang menjadi surga bagi para penghuninya, baik surga dunia maupun sebagai penghantar menuju surga akhirat.

\section{Peran Orang Tua pada Pendidikan dalam Keluarga}

Peran orang tua dalam proses pendidikan adalah menggunakan semua sarana atau metode seperti memberi keteladan bagi anaknya, dengan metode nasehat, kisah sampai kepada hukuman. Demikian juga orang tua hendaknya memberikan materi pendidikan seperti pendidikan agama, sosial, jasmani, moral, akal dan sebagainya. Termasuk peran orang tua dalam pendidikan adalah memperhatikan kunci keberhasilan pendidikan yaitu ikhlash, doa, sabar dan juga komitmen dalam menentukan suatu metode pendidikan.

\section{KESIMPULAN DAN SARAN}

\section{Kesimpulan}

Tujuan adanya pendidikan keluarga adalah menjadikan keluarga yang harmonis, keluarga yang penuh nilai-nilai kebaikan terbina kasih sayang, penuh cinta dan kesejukan. Dengan pendidikan kelurga akan mencetak anak-anak yang tangguh, mental yang kuat, akidah yang kokoh, berbakti kepada orang tua, dan punya akhlak yang baik, sehingga siap menyambut masa depan dan menjadi pelopor-pelopor kebaikan di masyarakat.

Peran orang tua dalam proses pendidikan dalam keluarga adalah, Pertama; Ikut aktif dalam proses pendidikan. Kedua; menjadi teladan dalam keluarga. Ketiga; 
menggunakan sarana-sarana atau metode seperti metode nasehat, kisah, peristiwa atau hukuman. Keempat; orang tua hendaknya memberikan materi pendidikan kepada anak-anaknya seperti pendidikan agama, sosial, jasmani, moral, akal dan sebagainya. Kelima; hendaknya menempuh cara agar berhasil dalam melakukan proses pendidikan, yaitu orang tua dan anak ikhlash di dalam melakukan proses pendidikan, senantiasa berdoa kepada Allah, sabar dan juga komitmen dalam melakukan proses pendidikan.

\section{Saran}

Dengan adanya tulisan ini diharapkan kepada para pendidik terutama para orang tua untuk lebih peduli dan memperhatikan pendidikan agama dan akhlak kepada anakanaknya.

\section{DAFTAR PUSTAKA}

Ulwan, Abdullah Nashih. (1992). Tarbiyatul Aulād Fil Islām, Beirut: Darus Salam, cet.21

Abdurrahman ,Jamal. (2004). Athfālul Muslimīn Kaifa Robbahum Annabiyyu al-Amīn, Makkah: Dar Thoyyibah al-Khodhro", cet,7

al-Jauziyah, Ibnu Qoyyim. (2009). Țhfah Al-Maudūd bi Ahkamil Maulūd, Makkah: Daarul 'Alam al-fawaaid, cet,1

Al Habsyi ,Ahmad .(2014). Ada Surga di Rumahmu 7 Keajaiban Orang Tua, Tangerang Selatan: Haqiena Media, Cet , II

Mu'thi, Abdul, Muhammad, Abdullah. (2008). Be a Jenius Teacher Mendidik dengan Kreatif, Surabaya : Pustaka eLBA,cet : I

A. Ibrohim, Qosim dan A. Saleh, Muhammad, A. Saleh. (2004). Buku Pintar Sejarah Islam Jakarta : Zaman.

Adwi, Musthofa. (1992). Ahkamul At Thifli, Riyadh : Darul Hijrah

Suwaid, Nur, Muhammad. (1990). Manhaj, At Tarbiyah An Nabawiyah li Thifli, Kuwait : Daar Ibnu Katsir

Al Barijawi, Abdul Lathif. (2009). Fiqhul Usroh Almuslimah ma'alim At Tarbawiyah lil Usroh Rasyidah, Suriah : Maktabah Nur

Khoiriyah. (2014). Karakter Pendidikan Dalam Al Quran, Tesis, Malang: UIN Maulana Malik Ibrahim Malang,

Ainissyifa, Hilda. (2014). Pendidikan Karakter dalam Perspektif Pendidikan Islam. Jurnal Pendidikan UNIGA 8.1 (2014): 1-26.Garut : Universitas Garut 
Taubah, Mufatihatut. (2015). Pendidikan Anak Dalam Keluarga Perspektif Islam. Jurnal Pendidikan Agama Islam (Journal of Islamic Education Studies), 3(1), 109-136.

Syafe'i, Imam. (2015). Tujuan Pendidikan Islam. Al-Tadzkiyyah: Jurnal Pendidikan Islam, 6 (2), 151-166. Lampung : IAIN

Jailani, M. Syahran. (2014) Teori Pendidikan Keluarga dan Tanggung Jawab Orang Tua dalam Pendidikan Anak Usia Dini. Jurnal. 8.2 (2014): 245-260. Jambi : IAIN Sulthan Thaha Saifuddin

Aroma, Iga Serpianing, and Dewi Retno Suminar. (2012). Hubungan antara tingkat kontrol diri dengan kecenderungan perilaku kenakalan remaja. Jurnal Psikologi Pendidikan dan Perkembangan 1.2 (2012): 1-6. Surabaya: Universitas Airlangga

Al-Qur'an Perkata Indonesia dan Inggris. (2014). Terjemah Kementrian Agama RI. Jakarta : Kalam Media Ilmu

Ulya, Nur Maziyah (2012). Pemikiran Ibnu Qayyim Al Jauziyyah Tentang Pendidikan Prenatal Dalam Kitab Tuhfah Al Maudūd Bi Ahkām Al Maulūd. Tesis . Semarang: IAIN Walisongo, Semarang

Moleong, (2016), Metodologi Penelitian Kualitatif, Bandung: PT remaja rosdakarya, cet.35

Rusdiana. (2015). Pengelolaan Pendidikan, Bandung : CV Pustaka Setia

Albani, Nasruddin. (2007). Shifat Sholat Nabi, Bandung : Gema Risalah Press

Sugiono. (2015). Metode penelitian pendidikan, Bandung: Alfabeta, cet.21

Fariq. (2002). Bengkel Akhlak, Jakarta : Darul falah 